\title{
Petrocodon villosus (Gesneriaceae), a new species from Guangxi, China
}

\author{
X. Hong ${ }^{1,3,4}$, S.-B. Zhou ${ }^{1,3^{*}}$, F. Wen ${ }^{2,4^{*}}$
}

Key words

Gesneriaceae

Guangxi

new species

Petrocodon

$P$. villosus

taxonomy

\begin{abstract}
A new species of Gesneriaceae from south-western Guangxi, China, Petrocodon villosus, is described and illustrated. It resembles $P$. ferrugineus, but is differentiated by several characters, such as the size of bracts, calyx and corolla, the indumentum of leaf blades, calyx, filaments and the outside of the corolla; the corolla tube shape, limb and lobes, the disc and stigma. A description of $P$. villosus, together with illustrations, habitat description and a diagnostic comparison are presented.
\end{abstract}

Published on 6 June 2014

\section{INTRODUCTION}

The genus Petrocodon Hance (Gesneriaceae) was established in 1883 with one species, $P$. dealbatus Hance. In 1975 a second variety, P. dealbatus Hance var. denticulatus W.T.Wang was recognised. Recently a further three species, $P$. ferrugineus Y.G.Wei (2007), P. multiflorus F.Wen \& Y.S.Jiang (2011), $P$. lancifolius F.Wen \& Y.G.Wei (2012), were described. In addition, the circumscription of allied genera proved to be artificial (Möller et al. 2009) and based on molecular studies (Möller et al. 2009, 2011, Wang et al. 2011, Weber et al. 2011), some Chinese monotypic genera, namely Calcareoboea C.Y.Wu ex H.W.Li (1982), Paralagarosolen Y.G.Wei (2004), Dolicholoma D.Fang \& W.T.Wang (1983), Tengia Chun (1946), Lagarosolen W.T.Wang (1984) and a few species of Didymocarpus Wall. (1819), were incorporated into Petrocodon. Thus, the genus now comprises at least 20 species in China (Möller et al. 2011, Wang et al. 2011, Weber et al. 2011), and emerges as one of the florally most diverse clades of Old World Gesneriaceae (Weber et al. 2011).

In recent years, a large number of new species have been reported from limestone areas in South China and North Vietnam, most have narrowly restricted distributions and are usually endemic. In 2010, we collected a rare plant of Gesneriaceae from karst limestone hills in the south-western Guangxi. The plant at first looked like $P$. ferrugineus because of a similar leaf shape and leaf hair morphology. Unfortunately, it was not flowering. Over the past two years, the living plants were monitored in the field and an ecological survey was carried out. After we collected specimens with flowers, we were surprised to find that the flower structures of two species are different. While consulting the rele-

\footnotetext{
College of Life Sciences, Anhui Normal University, CN-241000, Wuhu, China; e-mail: hongxin200710084@126.com, zhoushoubiao@vip.163.com.

2 Guangxi Key Laboratory of Functional Phytochemicals Research and Utilization, Herbarium, Guangxi Institute of Botany, Guangxi Zhuang Autonomous Region and the Chinese Academy of Sciences, CN-541006 Guilin, China; *corresponding author's e-mail: wenfang760608@139.com.

3 The Key Laboratory of Conservation and Employment of Biological Resources of Anhui, CN-241000, Wuhu, China.

${ }^{4}$ Gesneriad Conservation Center of China, Guangxi Zhuang Autonomous Region and the Chinese Academy of Sciences, CN-541006 Guilin, China. * Authors for correspondence.
}

vant literature (Wang 1990, He \& Cong 1992, Wu \& Ku 1997, Wang et al. 1998, Li \& Wang 2004, Wei 2007, Wei et al. 2010, Jiang et al. 2011, Wang et al. 2011, Xu et al. 2012, Wen et al. 2012), we concluded that it is an hitherto undescribed species. Petrocodon villosus is morphologically most similar to $P$. ferrugineus, both found in south-western Guangxi. They have a similar elliptic-ovate or oblong shaped leaf and coriaceous or subcoriaceous leaf texture, in contrast to all other species of Petrocodon, where the shapes of the leaves are diverse (lanceolate, oblanceolate, elliptic, broadly ovate, orbicular, sometimes falcate) and the leaf texture is commonly herbaceous or papyraceous. However, the two can be easily distinguished by a number of characteristics (see Table 1).

\section{Petrocodon villosus Xin Hong, F.Wen \& S.B.Zhou, sp. nov. - Fig. 1, 2}

Differs from Petrocodon ferrugineus Y.G.Wei by leaf blades adaxially sparsely strigose to glabrous, bracts 2.5 by $0.5 \mathrm{~mm}$, calyx c. $2.5 \mathrm{~mm}$ long inner surface glabrous, corolla $1-1.2 \mathrm{~cm}$ long with narrowly infundibuliform tube, limb distinctly 2-lipped, outside white, sparsely puberulent, lobes ovate-triangular to obliquely ovate, straight, glandular-pubescent, filaments and capitate staminodes inserted at c. $4 \mathrm{~mm}$ above the corolla base respectively, disc $1 \mathrm{~mm}$ high with an elongated projection or horn on one side, stigma bipartite. Type: F. Wen 0173 (holo IBK; iso ANU), China, Guangxi Autonomous Region, Baise City, Debao Country, Yandong Town, growing in rocky crevices at the foot of a limestone hill, N23 ${ }^{\circ}$ ', E106 ${ }^{\circ} 39^{\prime}$, elevation c. 160 m, 27 Nov. 2012.

Etymology. The specific epithet is derived from the particular villous aspect of the leaf blades and petioles.

Perennial rosette herb, acaulescent. Rhizome subterete, erect or ascendant, $1.8-2.2 \mathrm{~cm}$ long, $0.5-0.7 \mathrm{~cm}$ diam, rooting at the nodes. Leaves $9-15$ or more, basal; petioles $2-3 \mathrm{~cm}$, brownish strigose; leaf blade coriaceous to subcoriaceous, slightly oblique, elliptic-ovate or oblong, $4-4.5$ by $2.6-3 \mathrm{~cm}$, adaxially sparsely strigose to glabrous, abaxially densely brownish villous, base broadly cuneate, upper surface green, surface below russet, margin crenate, apex obtuse, lateral nerves 3-5 nerves on each side, adaxially impressed, abaxially prominent, densely brownish strigose. Cymes 1-3, 8-11-flowered; peduncles $6-8(-15) \mathrm{cm}$ long, extremely short brownish pubescent. Bracts 2, linear or lanceolate-linear, c. 2.5 by 0.5 $\mathrm{mm}$, outside strigose, inside glabrous. Pedice/s $3-5 \mathrm{~mm}$ long, 
sparsely brownish pubescent. Calyx 5-parted to the base, lobes narrowly lanceolate-linear, c. $2.5 \mathrm{~mm}$ long, outer surface extremely short brownish pubescent, inner surface glabrous. Corolla white, throat with two distinctly elliptic yellow spots, $1-1.2 \mathrm{~cm}$ long, outside sparsely pubescent, inside glabrous, orifice slightly swollen, $0.3-0.4 \mathrm{~cm}$ diam; tube narrowly infundibuliform, $0.7-0.8 \mathrm{~cm}$ long; limb distinctly 2-lipped, adaxial lip 2-parted to half-length, lobes obliquely ovate, c. 2.5 by $1.5 \mathrm{~cm}$, apex acute to obtuse; abaxial lip 3-parted to one third, lobes equal, ovate-triangular, c. 0.4 by $0.2 \mathrm{~cm}$, apex acute. Stamens 2, adnate c. $4 \mathrm{~mm}$ above the corolla base; filaments c. $2 \mathrm{~mm}$ long, straight, scattered glandular-pubescent, anthers black, fused by their entire adaxial surfaces, ellipsoidal, c. $1 \mathrm{~mm}$ long, glabrous; staminodes 2, capitate, c. $0.5 \mathrm{~mm}$ long, glabrous, inserted c. $2 \mathrm{~mm}$ from the base of the corolla. Disc annular 1-2 $\mathrm{mm}$ high, having an elongated projection or horn on one side. Pistil 10-12 mm, c. $2 \mathrm{~mm}$ diam; ovary linear, 6-8 mm long, densely puberulent with both glandular and eglandular hairs; style linear, 3-4 mm long, glandular-puberulent. Stigma bipartite, c. $0.3 \mathrm{~mm}$ long, lobes ovate, parted to half-length, apex obtuse. Capsule linear, straight, $2-2.5 \mathrm{~cm}$ long, 1.5-2 $\mathrm{mm}$ diam, glandular-pubescent and sparsely pilose.

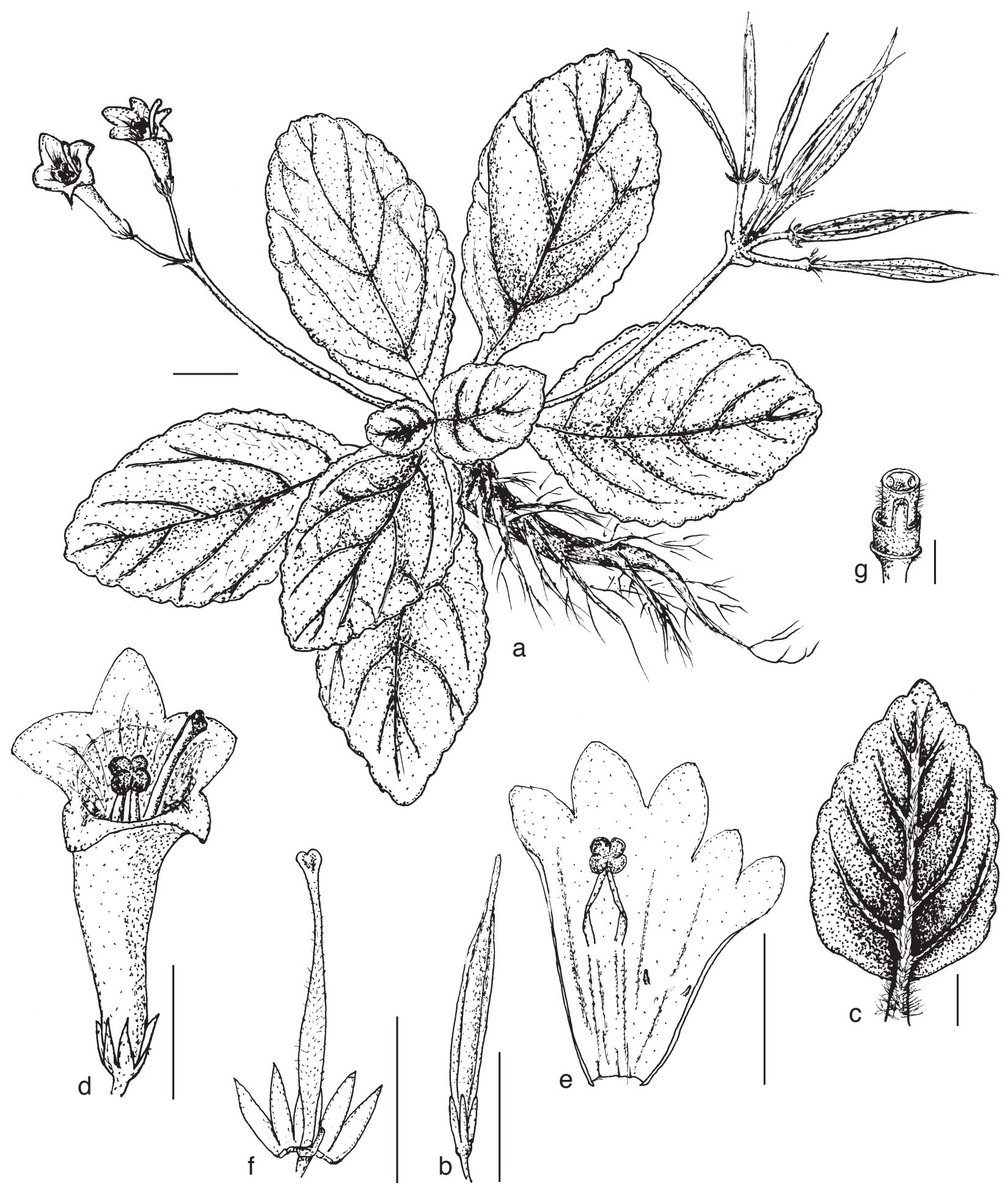

Fig. 1 Petrocodon villosus Xin Hong, F.Wen \& S.B.Zhou. a. Mature individual, habit; b. mature capsule; c. abaxial leaf; d. flower; e. opened corolla for showing stamens and staminodes; f. pistil and opened calyx lobes; g. transverse section of ovary with the annular nectary at base (all: $F$. Wen 0173 , IBK). - Scale bars: $a-c=1 \mathrm{~cm} ; \mathrm{d}-\mathrm{f}=5 \mathrm{~mm} ; \mathrm{g}=1 \mathrm{~mm}$. - Drawn by Ms. H.M. Xiao. 


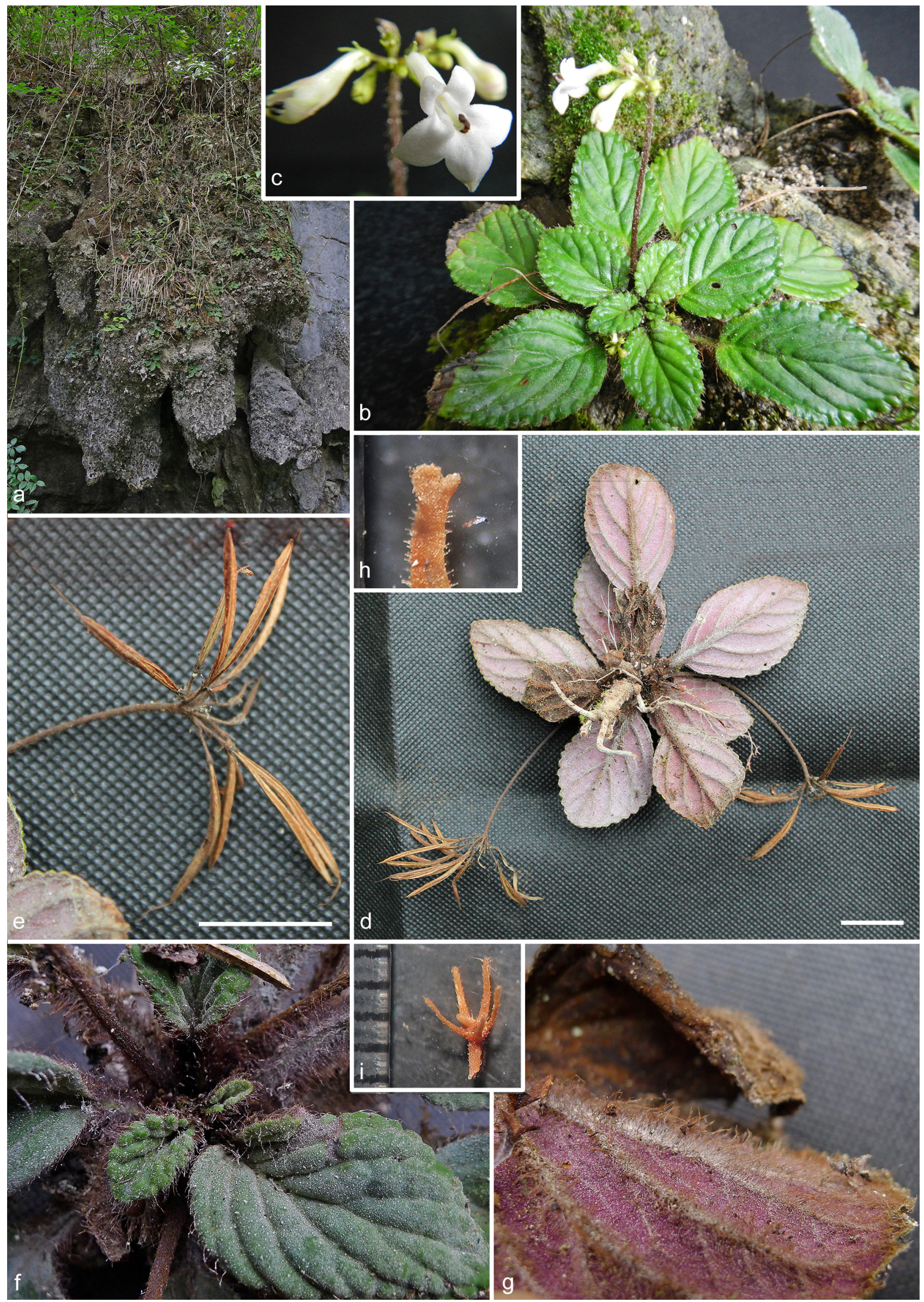

Fig. 2 Petrocodon villosus Xin Hong, F.Wen \& S.B.Zhou. a. Habitat; b. mature individual, habit; c. open flower and cyme; d. underside of plant; e. fruits; f. indumentum of young leaves and petioles; g. brown indumentum of abaxial leaf; h. stigma; i. opened calyx lobes and annular nectary with an elongated projection or horn on one side. - Photos: a-g. Fang Wen; h, i. Xin Hong. 
Table 1 Comparison of Petrocodon villosus and P. ferrugineus.

\begin{tabular}{|c|c|c|}
\hline Character & P. villosus & $P$. ferrugineus \\
\hline Indumentum of leaves & $\begin{array}{l}\text { adaxially sparsely strigose to glabrous, abaxially densely } \\
\text { brownish villous }\end{array}$ & densely brownish villous on both surfaces \\
\hline Bracts & 2.5 by $0.5 \mathrm{~mm}$ & $4-5$ by $1 \mathrm{~mm}$ \\
\hline Calyx & c. $2.5 \mathrm{~mm}$ long, outer surface pubescent, inner surface glabrous & $1-2 \mathrm{~mm}$ long, with dense ferruginous pubescence on both surfaces \\
\hline Corolla & $\begin{array}{l}1-1.2 \mathrm{~cm} \text { long, tube narrowly infundibuliform, outside white, } \\
\text { sparsely puberulent }\end{array}$ & 4-5 mm long, tube campanulate, outside purplish brown strigulose \\
\hline Limb of corolla & $\begin{array}{l}\text { distinctly 2-lipped, adaxial lip 2-parted to half-length, lobes } \\
\text { obliquely ovate; abaxial lip 3-parted to one third, lobes } \\
\text { ovate-triangular }\end{array}$ & $\begin{array}{l}\text { inconspicuously zygomorphic, adaxial lip 2-parted to the base, } \\
\text { lobes deltoid; abaxial lip 3-parted close to the base, lobes deltate } \\
\text { to ovate }\end{array}$ \\
\hline Filaments & $\begin{array}{l}\text { straight, scattered glandular-pubescent, inserted about } 4 \mathrm{~mm} \\
\text { above the corolla base }\end{array}$ & $\begin{array}{l}\text { curved, glabrous, inserted about } 1 \mathrm{~mm} \text { above the base of the } \\
\text { corolla }\end{array}$ \\
\hline Staminodes & capitate, inserted c. $2 \mathrm{~mm}$ from the base of the corolla & linear, straight, inserted $0.5-0.8 \mathrm{~mm}$ from the base of the corolla \\
\hline Disc & c. 1-2 mm high, with an elongated projection or horn on one side & c. $0.5 \mathrm{~mm}$ high, annular \\
\hline Stigma & bipartite, lobes ovate & spheroidal \\
\hline
\end{tabular}

Distribution - China (narrowly endemic and known only from the type locality, i.e. Yandong Town (N23 $\left.{ }^{\circ}{ }^{\prime}, \mathrm{E}_{106^{\circ}} 39^{\prime}\right)$, c. $11 \mathrm{~km}$ south-west of Debao Country, Baise City, southern Guangxi Zhuangzu Autonomous Region, China.

Habitat \& Ecology - Petrocodon villosus is locally abundant. It grows on moist and shaded rock faces on the cliff around the cave mouth at the foot of a limestone hill at an elevation of $160 \mathrm{~m}$ asl. The average temperature of Debao County is about $22.3^{\circ} \mathrm{C}$, the average annual precipitation is over $1000 \mathrm{~mm}$. The forest where $P$. villosus occurs is subtropical evergreen broad-leaved forest. Flowering is from October to November.

Additional specimens. CHINA, Guangxi Autonomous Region, Baise city, Debao Country, Yandong Town, alt. 160 m, 4 Aug. 2010, Wang-062 (IBK, K); ibid., 160 m, 27 Nov. 2012, Hong 20121116 (ANU, K).

Acknowledgements The authors are grateful to Prof. Yi-Gang Wei and Prof. Xin-Hu Guo for checking the specimens and reviewing the description of this new species, and Miss Hong-Mei Xiao for drawing the handsome illustration. The authors also would like to thank Mr. Hua Wang for his advice on the living specimen collection. This study was supported by Key Foundation of Education Department of Anhui Province (KJ2011A129), Provincial Key Laboratory of Biotic Environment and Ecological Safety in Anhui (2004sys003), Director Fund project of Guangxi Key Laboratory of Functional Phytochemicals Research and Utilization (ZRJJ2012-9), Science Research Foundation of Guangxi Academy of Sciences (no. 12YJ25ZW013), West Light Foundation of The Chinese Academy of Sciences, International S \& T Cooperation Projects of Guangxi (Guikehe 1347004-4) and Guilin (Shike [2013]79), the Guangxi Natural Science Foundation (No. 2013GXNSFAA019071).

\section{REFERENCES}

Chun WY. 1946. Gesneriacearum novae Sinicarum. Sunyatsenia 6: 271-304. Hance HF. 1883. New Chinese Cyrtandreae. Journal of Botany 21: 165-170. He SZ, Cong XD. 1992. A new species of Tengia (Gesneriaceae). Journal of China Pharmaceutical University 23: 269-271. In Chinese.

Jiang YS, Zhang Y, Wang Y, Wen F. 2011. Petrocodon multiflorus sp. nov. (Gesneriaceae) from Guangxi, China. Nordic Journal of Botany 29: 57-60.

Li HW. 1982. Two new genera and one little known genus of Gesneriaceae from Yunnan. Acta Botanica Yunnanica 4: 241-247.

Li ZY, Wang YZ. 2004. Plants of Gesneriaceae in China. Henan Science \& Technology Publishing House, Zhengzhou.

Möller M, Pfosser M, Jang CG, Mayer V, Clark A, et al. 2009. A preliminary phylogeny of the didymocarpoid Gesneriaceae based on three molecular data sets: incongruence with available tribal classifications. American Journal of Botany 96: 989-1010.

Möller M, Forrest A, Wei YG, Weber A. 2011. A molecular phylogenetic assessment of the advanced Asiatic and Malesian didymocarpoid Gesneriaceae with focus on non-monophyletic and monotypic genera. Plant Systematics and Evolution 292: 223-248.

Wallich N. 1819. Notice of the progress of botanical science in Bengal [letter to F. Hamilton]. Edinburgh Philosophical Journal 1: 376-381.

Wang WT. 1984. Notulae de Gesneriaceis Sinensibus VI. Acta Botanica Yunnanica 6: 11-26.

Wang WT. 1990. Gesneriaceae. In: Wang WT (ed), Flora Reipublicae Popularis Sinicae Vol. 69: 125-581. Science Press, Beijing.

Wang WT, Pan KY, Li ZY, Weitzman AL, Skog LE. 1998. Gesneriaceae. In Wu ZH, Raven PH (eds), Flora of China 18. Science Press, Beijing \& Missouri Botanical Garden Press, Saint Louis.

Wang YZ, Mao RM, Liu Y, Li JM, Dong Y, Li ZY, Smith JF. 2011. Phylogenetic reconstruction of Chirita and allies (Gesneriaceae) with taxonomic treatments. Journal of Systematics and Evolution 49: 50-64.

Weber A, Wei YG, Puglisi C, Wen F, Mayer V, Möller M. 2011. Anew definition of the genus Petrocodon (Gesneriaceae). Phytotaxa 23: 49-67.

Wei YG. 2004. Paralagarosolen Y.G.Wei, a new genus of the Gesneriaceae from Guangxi, China. Journal of Systematics and Evolution 42: 528-532.

Wei YG. 2007. Petrocodon ferrugineus (Gesneriaceae), a new species from Guangxi, China. Novon 17: 135-137.

Wei YG, Wen F, Möller M, Monro A, Zhang Q, et al. 2010. Gesneriaceae of South China. Guangxi Science and Technology Publishing House, Nanning.

Wen F, Liang GY, Wei YG. 2012. Petrocodon lancifolius (Gesneriaceae), a new species endemic to a central subtropical zone of Guizhou Province, China. Phytotaxa 49: 45-49.

Wu CY, Ku TC. 1997. New taxa of the Begonia L. (Begoniaceae) from China (continued). Acta Phytotaxonomica Sinica 35: 43-56.

Xu WB, Huang YS, Peng RC, Zhuang XY. 2012. Hemiboea sinovietnamica sp. nov. (Gesneriaceae) from a limestone area along the boundary of SinoVietnam. Nordic Journal of Botany 30: 691-695. 